\title{
Early Generation Evaluation in Antirrhinum majus for Prediction of Cutflower Postharvest Longevity
}

\author{
William J. Martin'1 and Dennis P. Stimart ${ }^{2}$ \\ Department of Horticulture, University of Wisconsin-Madison, 1575 Linden Drive, Madison, WI 53706
}

\begin{abstract}
AdDitional INDEX WORDS. vase life, postharvest keeping quality, on-plant longevity, heritability, indirect selection, genetic variance

Abstract. On-plant floret longevity and cutflower postharvest longevity (PHL) of Antirrhinum majus L., snapdragon, were evaluated using inbreds P1 (16 day PHL) and P2 (6 day PHL), F $(P 1 \times P 2), F_{2}\left(F_{1}\right.$ self-pollinated), $F_{2} \times F_{2}(a m o n g$ and within PHL categories: long, 17 to 25 days; middle, 9 days; and short, 2 to 3 days), and $F_{3}$ families ( $F_{2}$ self-pollinated). $F_{2}$ on-plant floret longevity and PHL correlated to later generation PHL. Prediction of progeny PHL from $F_{2} \times F_{2}$ matings appears feasible if genotypic value for PHL of $F_{2}$ is known. Selection for PHL is best based on evaluation of multiple cutflowers per genotype. Significant additive and dominant genetic variance components contribute to PHL.
\end{abstract}

Cutflowers are highly perishable and cutflower postharvest longevity (PHL) is critical to market value. Historical and current research uses chemical treatments to extend PHL by only a few days. Several of these compounds are carcinogens, long lasting in the environment, and toxic at low concentrations (Nell, 1992; Ohkawa et al., 1999). With chemicals available to industry being limited in efficacy and in number, a need exists to explore alternative methods of extending PHL.

Despite the importance of PHL in determining quality and consumer preference, information on inheritance and response to selection for PHL remains scarce. Variability for PHL has been observed in Antirrhinum majus L. (Stieve and Stimart, 1994), Begonia $\times$ cheimantha Everett (Hvoslef-Eide et al., 1995), Callistephus chinensis L. (Patil and Rane, 1999), Eustoma sp. Raf. (Ohkawa and Sasaki, 1999), Leptospermum sp. (Bicknell, 1995), Limonium sp. (Burge etal., 1998), Lupinus havardii Wats (Mackay and Davis, 1998), Paeonia sp. (Heuser and Evensen, 1986), and members of the Proteaceae (Joyce and Beal, 1999). Genetic variance components, of greater immediate utility for improving PHL, have been reported in: A. majus (Schroeder and Stimart, 2001), Dendrobium cultivars (Bobisud and Kamemoto, 1982), Gerbera sp. (Muceniece et al., 1978; Wernett et al., 1996a), Lilium sp. (van der Meulen-Muisers et al., 1998, 1999), Rosa cultivars (De et al., 1999), and Tulipa sp. (van Eijk and Eikelboom, 1980). Direct and indirect selection for PHL, performed upon the trait of interest or correlated traits, respectively, has been proposed for Gerbera sp. (Wernett et al., 1996a, 1996b), Lilium sp. (van der MeulenMuisers and van Oeveren, 1996; van der Meulen-Muisers et al., 1997), Petunia sp. (Krahl and Randle, 1999), Rosa sp. (Halevy and Mayak, 1975), and Tulipa sp. (van Eijk and Eikelboom, 1980). Selection response against stem bending, folding and wilting (Wernett et al., 1996a), and for productivity as yield in flowering stems (Harding et al., 1981) have been reported in Gerbera populations. Successful selection in Dianthus caryophyllus L. for postharvest flower life was recently described by Burchi et al. (1999) and Onozaki et al. (2001).

Received for publication 3 Dec. 2002. Accepted for publication 16 June 2003. A note of gratitude to Erik Nordheim, University of Wisconsin-Madison, for statistical consultation during preparation of this manuscript. Use of trade names does not imply endorsement of the products named or criticism of similar ones not named.

${ }^{1}$ Graduate research assistant.

2Professor and chair; to whom reprint requests should be addressed; e-mail dstimart@facstaff.wisc.edu.
Development of commercial ornamental breeding lines is a lengthy and resource-consuming process even considering relatively short lifecycles. Analysis of A. majus PHL is based on lifecycle attributes of the species, genetic variability for PHL, and with the goal to extend PHL through breeding. Preliminary work in A. majus genetics revealed PHL as a readily manipulated, quantitative trait with significant additive and dominant genetic components (Schroeder, 1995, 2000; Schroeder and Stimart, 2001). Further, selection for PHL in A. majus is possible and $F_{1}$ hybrids may be of utility to maximize PHL (Schroeder, 2000). This study investigated early generation crossing and evaluation to examine timing for selection, necessity of progeny testing, possibility for indirect selection, and resolution of underlying gene action for PHL in A. majus.

\section{Materials and Methods}

GeRMPLASM. Forty-seven commercial inbred lines of Antirrhinum majus L. were evaluated for PHL in 1991 and 1992 at the University of Wisconsin-Madison (Stieve and Stimart, 1994). Two lines selected represented extremes in PHL, P1 with $16 \mathrm{~d}$ and P2 with $6 \mathrm{~d}$ (Stieve and Stimart, 1994). Commercial A. majus inbreds are maintained through bulked pollen methods; therefore, P1 and P2 were self-pollinated and advanced by single seed descent to $\mathrm{F}_{6}$ to establish genetic purity. Inbreds were crossed in fall 1997 to produce $\mathrm{F}_{1}(\mathrm{P} 1 \times \mathrm{P} 2), 12 \mathrm{~d} \mathrm{PHL}$, and $\mathrm{F}_{2}\left(\mathrm{~F}_{1}\right.$ self-pollinated). Four hundred sixty $\mathrm{F}_{2}$ individuals were grown to anthesis in a polyhouse at the University of Wisconsin-Madison according to standard forcing procedures (Rogers, 1992). Briefly, seeds were germinated in a cell of a cell pack and seedlings individually transplanted to $96-\mathrm{cell}\left(65-\mathrm{cm}^{3}\right)$ flats. Seedlings were transplanted to square plastic pots $\left(1250 \mathrm{~cm}^{3}\right)$ when the third to fourth set of true leaves appeared and grown through anthesis. Growing medium consisted of equal volumes soil, peat and perlite. Plant bench spacing was on $22-\mathrm{cm}$ centers. Plants were fertilized every other week with $200 \mathrm{mg} \cdot \mathrm{L}^{-1} \mathrm{~N}$ using Peter's $20 \mathrm{~N}-8.7 \mathrm{P}-16.6 \mathrm{~K}$ (Scott's Sierra Horticultural Products Co., Marysville, Ohio) and provided supplemental light of $27 \mu \mathrm{mol} \cdot \mathrm{m}^{-2} \cdot \mathrm{s}^{-1}$ at bench level using 1000-W high-pressure sodium lamps from 0600 through $2400 \mathrm{HR} . \mathrm{F}_{2}$ plants were pinched above the third node and resulting axillary stems thinned to two stems per plant; other generations were not pinched.

Upon $\mathrm{F}_{2}$ anthesis, one stem was retained on the plant while the other stem was harvested for PHL evaluation. The stem for 


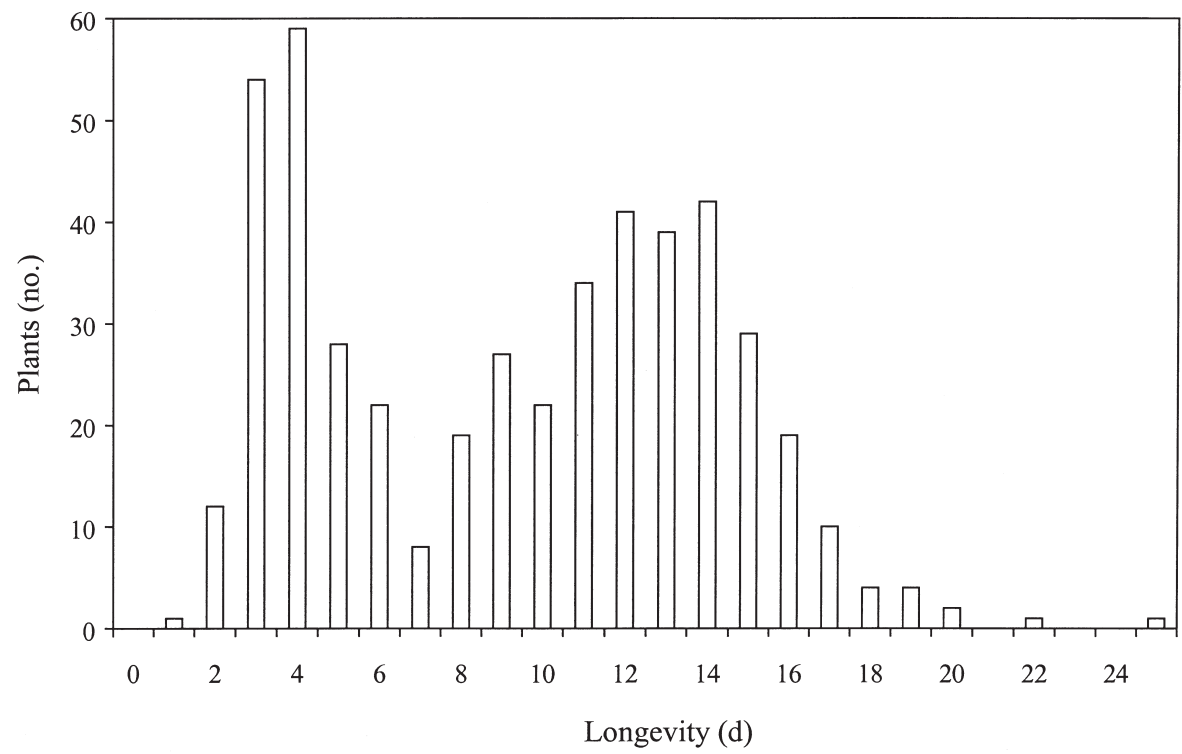

Fig. 1. Segregation in the $\mathrm{F}_{2}$ of Antirrhinum majus L. for cutflower postharvest longevity.

PHL evaluation was harvested when the first five florets opened thereby equalizing developmental stage. Harvested stems were immediately placed in distilled water $\left(\mathrm{dH}_{2} \mathrm{O}\right)$ and transported to the laboratory. Stems were adjusted to $40 \mathrm{~cm}$ below the lowest floret with the bottom $15 \mathrm{~cm}$ of leaves removed; the $40-\mathrm{cm}$ stem and inflorescence are herein termed cutflower. Cutflowers were placed in a $3 \times 5$ grid $(7.5 \times 7.5 \mathrm{~cm})$ supported upright with a wire mesh in plastic storage containers $34 \times 22 \times 15 \mathrm{~cm}(\mathrm{~L} \times \mathrm{W} \times$ $\mathrm{H})$ containing $3 \mathrm{~L}$ of $\mathrm{dH}_{2} \mathrm{O}$, a $4-\mathrm{cm}$ depth. Holding solutions were maintained daily by addition of $\mathrm{dH}_{2} \mathrm{O}$ but not exchanged. Cutflowers were evaluated at $23{ }^{\circ} \mathrm{C}$ under continuous cool white fluorescent illumination of $11 \mu \mathrm{mol} \cdot \mathrm{m}^{-2} \cdot \mathrm{s}^{-1}$ at bench level. Cutflower senescence was defined as $50 \%$ of the florets browning/drying or wilting (Marousky and Raulston, 1970). Dates of harvest and senescence were recorded for each cutflower and PHL determined from their difference.

The first five florets of each $\mathrm{F}_{2}$ were individually monitored for dates of anthesis and senescence using the on-plant stem. Floret senescence was defined as the floret wilting or $50 \%$ of the floret browning/drying. Difference between dates of floret anthesis and senescence is herein termed on-plant floret longevity. Upon completion of the on-plant study, $\mathrm{F}_{2}$ individuals were self-pollinated to create $\mathrm{F}_{3}$ families. $\mathrm{F}_{2}$ individual plants were randomly selected from extremes in PHL (long $=17$ to $25 \mathrm{~d}$ and short $=$ 2 to $3 \mathrm{~d}$ ) and the mean of the population (middle $=9 \mathrm{~d}$ ) (Fig. 1). Seventeen $F_{2}$ individuals were selected from each category; however, due to infertility several individuals were lost resulting in 15 individuals maintained per category. A half-diallel mating scheme within PHL categories and a full-diallel mating scheme among PHL categories, using the selected $\mathrm{F}_{2}$ individuals, were completed in Fall and Winter 1997-98 to create $\mathrm{F}_{2} \times \mathrm{F}_{2}$ progeny. Unrelated $\mathrm{F}_{2} \times \mathrm{F}_{2}$ progeny were selected for PHL evaluation to maximize the number of $\mathrm{F}_{2}$ individuals being progeny tested.

Thirty individuals from each of P1, P2, $F_{1}(\mathrm{P} 1 \times \mathrm{P} 2), 41 \mathrm{~F}_{3}\left(\mathrm{~F}_{2}\right.$ self-pollinated) families, and $68 \mathrm{~F}_{2} \times \mathrm{F}_{2}$ progeny were grown for PHL evaluations as described above. Due to logistic limitations, $\mathrm{F}_{2}$ $\mathrm{xF}_{2}$ progeny and corresponding $\mathrm{F}_{3}$ families were randomly assigned to three planting times. The plants were grown in a randomized complete block design (six blocks, five plants/genotype/block) in
Fall, Winter, and Spring 1998-99. Harvested stems were adjusted and evaluated for PHL as defined above.

Statistics. Data from Fall, Winter, and Spring 1998-99 plantings were checked for homogeneity of variances and seasonal effects on PHL. Samples of $F_{3}$ families, repeated over plantings, were used as controls; 18 between fall and spring, 10 between winter and spring, and two between fall and winter. Pair-wise comparisons of control means across plantings were completed (Littell et al., 1996; Steel and Torrie, 1980) and significant seasonal effects were not found. Equality of residual error variances across plantings was checked using Levene's test (Littell et al., 1996) to verify legitimacy of assumptions associated with linear regression analyses (Steel and Torrie, 1980). Residual errors were calculated and compared using mixed models analysis with Satterthwaite (1946) corrections for degrees of freedom (Littell et al., 1996). Specifically, plantings and genotypes were considered as fixed and other components of the experimental design as random (Littell et al., 1996; Steel and Torrie, 1980). Analysis confirmed uniformity of residual errors. Least-squares genotypic PHL means were calculated from the three plantings (Littell et al., 1996; Steel and Torrie, 1980). Linear regressions, to determine trait relationships, were completed using mixed model analysis with Satterthwaite (1946) corrections for degrees of freedom (Littell et al., 1996). $R^{2}$ values from regression were compared with established tables for significance (Steel and Torrie, 1980). Narrow sense heritability estimates were calculated as parentoffspring regressions (Falconer and Mackay, 1996).

Due to post-analysis inaccuracies in describing $\mathrm{F}_{3}$ family $\mathrm{PHL}$ based on $\mathrm{F}_{2}$ PHL, described below, classification of the $\mathrm{F}_{2} \times \mathrm{F}_{2}$ progeny into PHL categories was reassessed based on $\mathrm{F}_{3}\left(\mathrm{~F}_{2}\right.$ selfpollinated) family PHL values. Midparent values were calculated as if $\mathrm{F}_{2} \times \mathrm{F}_{2}$ progeny were generated from $\mathrm{F}_{3} \times \mathrm{F}_{3}$ crosses. Classification of nine evaluated $\mathrm{F}_{2} \times \mathrm{F}_{2}$ progeny, distributed across the PHL range, was not possible due to poor germination in related $\mathrm{F}_{3}$ families and thus were omitted from further analyses. Based on $\mathrm{F}_{3}$ family PHL means, midparent and high parent values were calculated for each of $59 \mathrm{~F}_{2} \times \mathrm{F}_{2}$ progeny evaluated (Hallauer and Miranda, 1988). Heterotic deviations of $\mathrm{F}_{2} \times \mathrm{F}_{2}$ progeny were quantified as day and percentage of deviation from the respective midparent and high parent PHL on a progeny basis and then averaged within cross categories. Positive average deviations represent progeny PHL values greater than midparent and high parent PHL, respectively. Least significant differences among average deviations were calculated (Littell et al., 1996).

\section{Results and Discussion}

$\mathrm{F}_{3}$ family cutflower PHL was significantly and positively correlated to $\mathrm{F}_{2}$ on-plant floret longevity, $R^{2}=0.22$ (Fig. 2B). Three non-outlier points influenced the significant, positive correlation of $\mathrm{F}_{2}$ individual PHL with $\mathrm{F}_{2}$ on-plant floret longevity, $R^{2}=0.09$ (Fig. 2A). Increased significance, with regard to $\mathrm{F}_{3}$ family versus $\mathrm{F}_{2}$ individual PHL, is likely due to greater precision of the $\mathrm{F}_{3}$ family mean due to increased sampling. On-plant longevity was generally two to three times longer than PHL (Fig. 2A and B). Correlations of on-plant floret longevity to PHL may suggest 

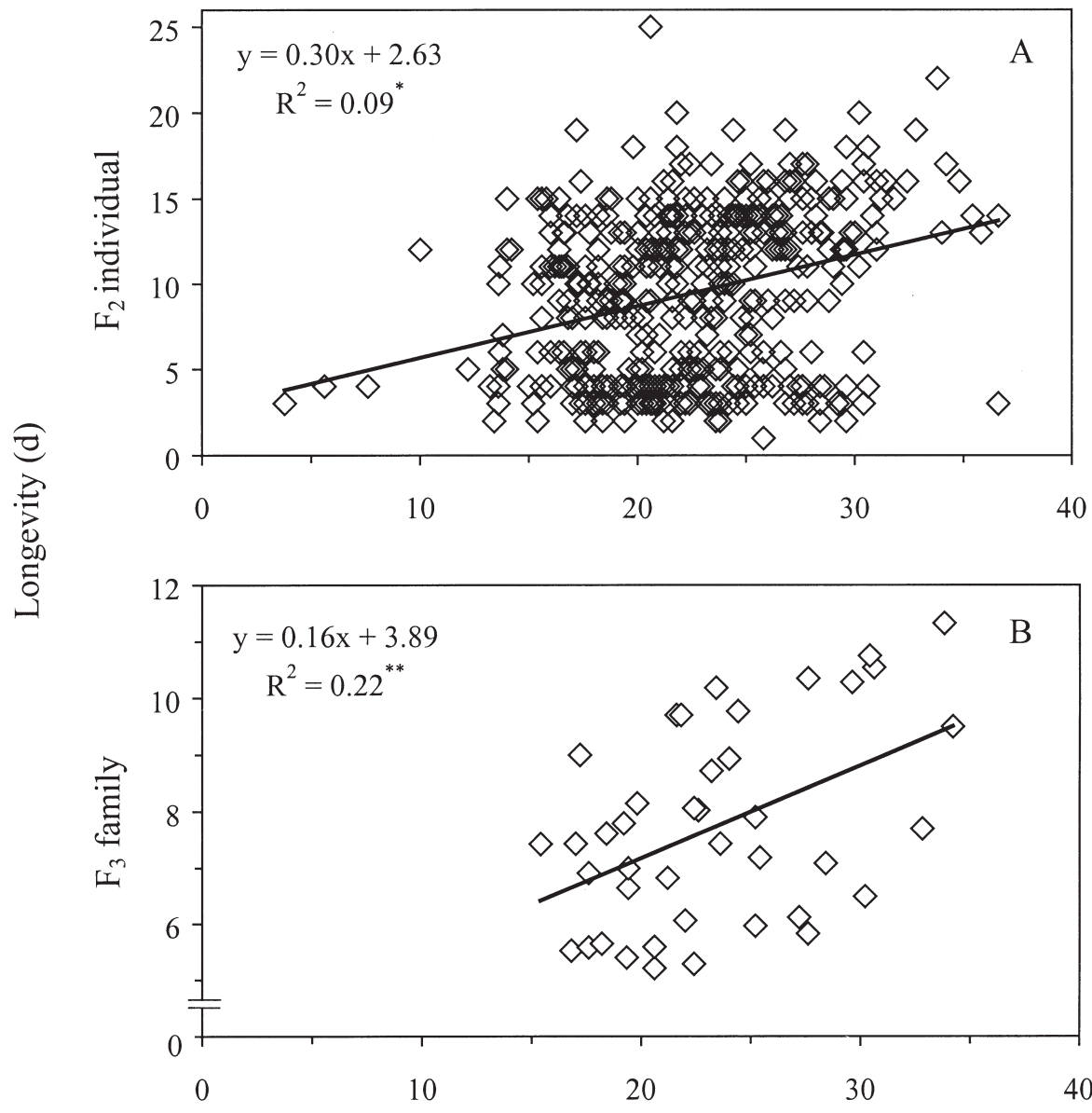

$\mathrm{F}_{2}$ on-plant floret longevity (d)

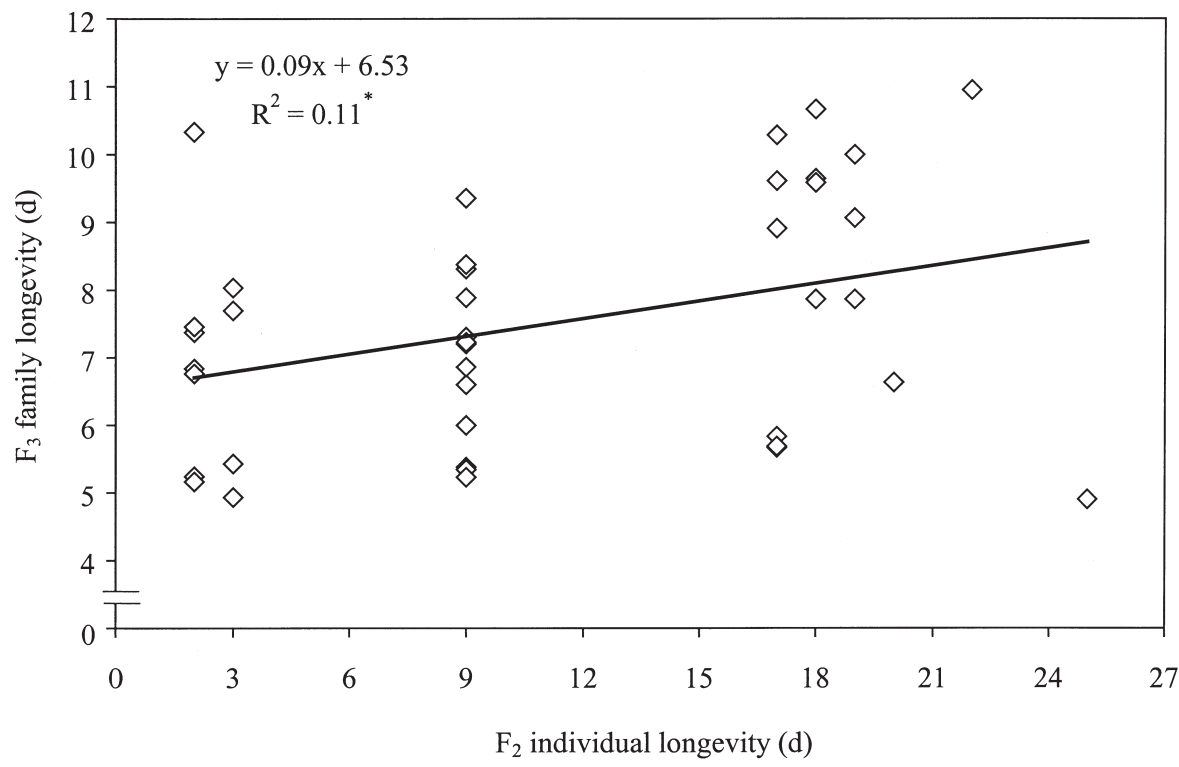

Fig. 3. Regression of $\mathrm{F}_{3}$ family cutflower postharvest longevity on $\mathrm{F}_{2}$ individual cutflower postharvest longevity in Antirrhinum majus L. *Significant at $P \leq 0.05$.

similar underlying floral senescence biology regardless of on-plant or cutflower evaluation since observed senescence symptoms were similar. $\mathrm{F}_{2}$ on-plant floret longevity provides information toward $\mathrm{F}_{2}$ individual and $\mathrm{F}_{3}$ family $\mathrm{PHL}$. Therefore, selection for extended
Fig. 2. Regression of $\mathrm{F}_{2}$ individual cutflower postharvest longevity $(\mathbf{A})$ and $\mathrm{F}_{3}$ average family cutflower postharvest longevity (B) on $\mathrm{F}_{2}$ on-plant floret longevity in Antirrhinum majus L. ${ }^{*} * *$ Significant at $P \leq 0.05$ or 0.01 , respectively.

PHL can be initiated in the $\mathrm{F}_{2}$ based on onplant longevity. Data from Lilium sp. (van der Meulen-Muisers et al., 1999), Petunia sp. (Krahl and Randle, 1999) and Tulipa sp. (van Eijk and Eikelboom, 1980) suggest similar correlations may hold across species.

$\mathrm{F}_{3}$ family $\mathrm{PHL}$ was significantly and positively correlated to $\mathrm{F}_{2}$ individual PHL, $R^{2}=0.11$ (Fig. 3). Observed ranges for $\mathrm{F}_{2}$ and $\mathrm{F}_{3}$ individual PHL were similar (data not shown); however due to averaging to obtain $\mathrm{F}_{3}$ means, the range for $\mathrm{F}_{3}$ family PHL was roughly one-half that of $\mathrm{F}_{2}$ individual PHL. Broad distributions of $\mathrm{F}_{3}$ PHL were observed within $\mathrm{F}_{2}$ PHLcategories (Fig. 3). The nature of these distributions and correlation magnitude suggest evaluation of $\mathrm{F}_{2}$ individual cutflower stems can be used, though very cautiously, to predict $\mathrm{F}_{3}$ family PHL. Due to the quantitative nature of A. majus PHL (Schroeder, 2000), sampling single $\mathrm{F}_{2}$ cutflowers is thought to be the main source of error in predicting $\mathrm{F}_{3}$ PHL. In contrast, sampling tails of a parental distribution is known to give accurate regression estimates (Nyquist, 1991). To improve 40 correlation between $\mathrm{F}_{2}$ and $\mathrm{F}_{3}$ PHL, multiple cutflowers from $\mathrm{F}_{2}$ plants may be evaluated and may be obtained by pinching or clonal propagation as in D. caryophyllus (Burchi et al., 1999; Onozaki et al., 2001). Evaluation for PHL can be accurately based on multiple $\mathrm{F}_{3}$ stems in preference to one $\mathrm{F}_{2}$ stem (Fig. 2A and B) (Schroeder and Stimart, 2001).

Matings of $\mathrm{F}_{2} \times \mathrm{F}_{2}$, within and among short, middle and long PHL categories, generated progeny with PHL values reflecting parental origin (Fig. 4). Crosses within PHL categories generated progeny that clustered in the respective categories. Matings among parental categories resulted in progeny of intermediate PHL. Regression of $\mathrm{F}_{2} \times \mathrm{F}_{2}$ progeny PHL values on midparent PHL values demonstrates a significant positive correlation, $R^{2}=0.71$ (Fig. 4). Multiple matings created for each cross category bolster the strong correlation. A narrow sense heritability estimate for PHL of 0.41 agrees with the narrow sense heritability of 0.30 obtained by Schroeder (2000). Based on a strong correlation, moderate heritability, and visual clustering of the data, prediction of $\mathrm{F}_{2} \times \mathrm{F}_{2}$ progeny PHL appears feasible if genotypic PHL value of $\mathrm{F}_{2}$ individuals is known. Similar results have been shown with intermating of Lilium cultivars (van der Meulen-Muisers et al., 1999).

Average $\mathrm{F}_{2} \times \mathrm{F}_{2}$ progeny PHL are a day, $\approx 24 \mathrm{~h}$, greater than respective midparent values without significant deviation across categories (Fig. 5, Table 1). Midparent PHL values for middle 


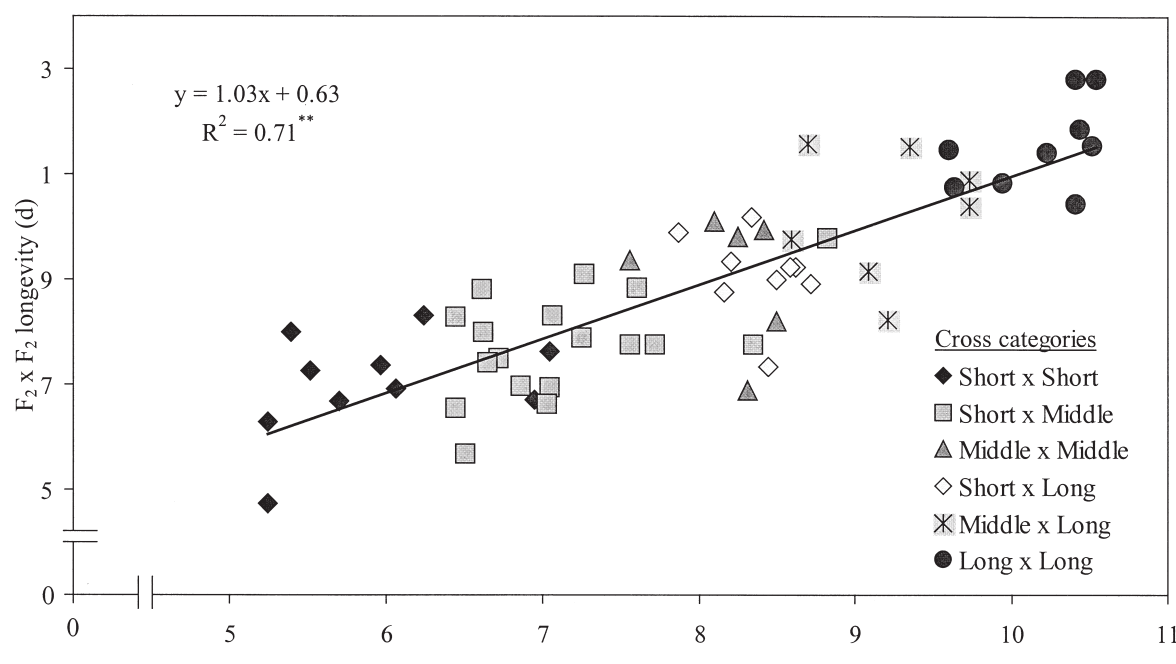

Midparent longevity (d)

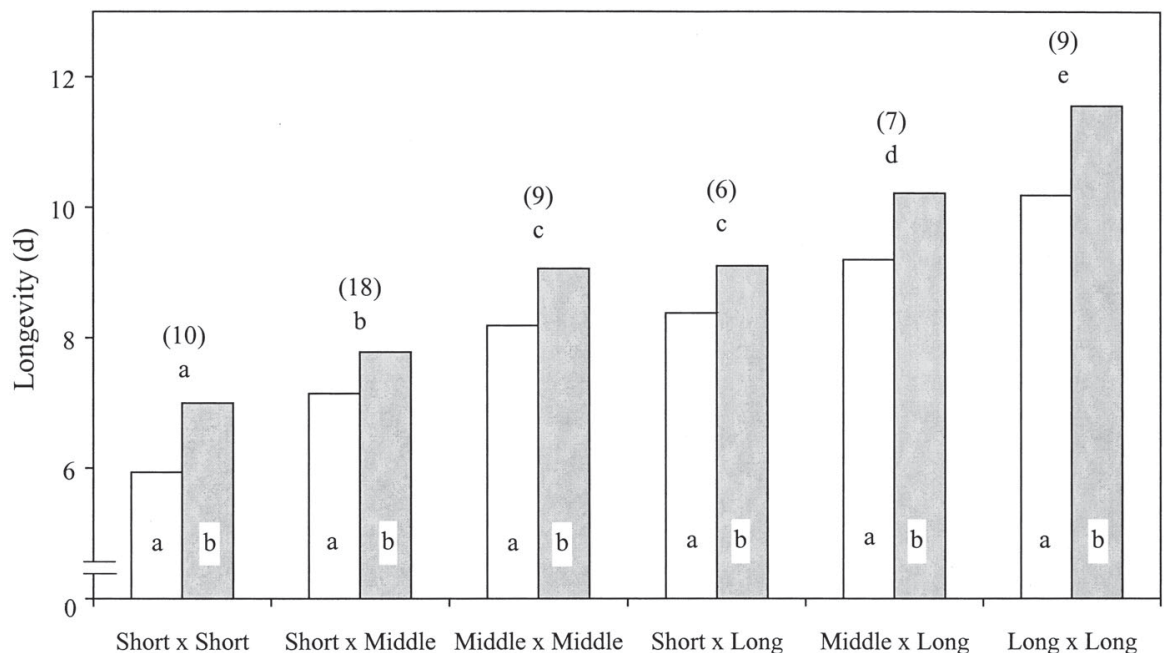

Cross category

Fig. 5. Average midparent (unshaded bars) and $\mathrm{F}_{2} \times \mathrm{F}_{2}$ progeny (shaded bars) cutflower postharvest longevity in Antirrhinum majus $\mathrm{L}$. for crosses made within and among cutflower postharvest longevity categories: short $=4.7-6.9 \mathrm{~d}$, middle $=7.2-8.4 \mathrm{~d}$, and long $=9.0-11.0 \mathrm{~d}$. Numbers in parenthesis represent number of crosses evaluated per cross category. Letters above columns represent mean separation of $\mathrm{F}_{2} \times \mathrm{F}_{2}$ progeny by LSD Ghd letters in columns represent mean separation of midparent and respective $\mathrm{F}_{2} \times \mathrm{F}_{2}$ progeny within a cross category by pair-wise $t$ test, $P \leq 0.05$.

Table 1. Average deviations of Antirrhinum majus $\mathrm{L} . \mathrm{F}_{2} \mathrm{x} \mathrm{F}_{2}$ progeny from midparent and high parent cutflower postharvest longevity calculated as days and percentage.

\begin{tabular}{|c|c|c|c|c|c|}
\hline \multirow[b]{2}{*}{ Cross categoryx } & \multirow[b]{2}{*}{$\mathrm{Nw}$} & \multicolumn{2}{|c|}{ Midparent ${ }^{2}$} & \multicolumn{2}{|c|}{ High parenty } \\
\hline & & Days & Percentage & Days & Percentage \\
\hline Short $\mathrm{x}$ short & 10 & $1.1 \mathrm{a}^{\mathrm{v}}$ & 17.8 & $0.8 \mathrm{ab}^{\mathrm{v}}$ & 13.1 \\
\hline Short $\mathrm{x}$ middle & 18 & $0.6 \mathrm{a}$ & 8.9 & $-0.2 \mathrm{c}$ & -2.0 \\
\hline Short $\mathrm{x}$ long & 6 & $0.7 \mathrm{a}$ & 8.7 & $0.5 \mathrm{abc}$ & 6.4 \\
\hline Middle $x$ long & 7 & $1.0 \mathrm{a}$ & 11.1 & $0.1 \mathrm{bc}$ & 0.7 \\
\hline Long $\mathrm{x}$ long & 9 & $1.4 \mathrm{a}$ & 13.4 & $1.0 \mathrm{a}$ & 9.7 \\
\hline
\end{tabular}

z(Parent A cutflower postharvest longevity + Parent B cutflower postharvest longevity)/2.

$y$ Greatest of Parent A or Parent B cutflower postharvest longevity in any given cross.

${ }^{x}$ Crosses between cutflower postharvest longevity categories: short $=4.7-6.9 \mathrm{~d}$, middle $=7.2-8.4 \mathrm{~d}$, and long $=9.0-11.0 \mathrm{~d}$.

wNumber of $\mathrm{F}_{2} \times \mathrm{F}_{2}$ progeny evaluated per cross category with 25-30 plants evaluated per progeny.

vMean separation by LSD, $P \leq 0.05$.
Fig. 4. Regression of cutflower postharvest longevity of $\mathrm{F}_{2} \mathrm{XF}_{2}$ progeny on midparent value in Antirrhinum majus L. Crosses made within and among cutflower postharvest longevity categories: short $=4.7-6.9 \mathrm{~d}$, middle $=7.2-8.4$ regression across categories, ${ }^{* *}$ Significant at $P \leq 0.01$.

$\mathrm{X}$ middle and short $\mathrm{x}$ long categories do not deviate significantly from each other nor do progeny from these groups deviate significantly; all other deviations are significant (Fig. 5). Significant differences among progeny of PHL cross categories (Fig. 5) suggest a signifithe significant additive variance reported by Schroeder and Stimart (2001). No significant differences across categories in deviation from midparent values (Fig. 5, Table 1) suggest a simple additive genetic model with partial dominance approximates the observed heterotic trend (Falconer and Mackay, 1996). A genetic model for A. majus PHL with additive and dominance components agrees with previous reports (Schroeder and Stimart, 2001).

Average deviations from high parent PHL varied $\pm 1 \mathrm{~d}$ and were significantly different across categories (Table 1). Average high parent deviations of progeny involving all PHL categories differ significantly among and within categories (Table 1). Lack of a simple trend in deviations from high parent PHL suggests genetic control of PHL is more complex than explained by a simple additive genetic model with partial dominance.

Prediction of $\mathrm{F}_{2} \times \mathrm{F}_{2}$ progeny PHL was most accurately based on respective $\mathrm{F}_{3}$ family PHL values. Based on data presented, selection of breeding lines for extended PHL is best completed after some form of multiple cutflower evaluation using $\mathrm{F}_{3}\left(\mathrm{~F}_{2}\right.$ self-pollinated $)$ families, $\mathrm{F}_{2} \mathrm{XF}_{2}$ progeny, or $\mathrm{F}_{2}$ clones. Evaluation of these generations should provide an effective means of predicting value of individuals or families per se and in cross combinations. Initial evaluation for PHL may be completed using $\mathrm{F}_{2}$ on-plant floret longevity and PHL of a single cutflower.

The quantitative nature and narrow sense heritability estimate $\mathrm{d}$, and long $=9.0-11.0 \mathrm{~d}$. Solid line represents linear cant additive component to PHLagreeing with 
for PHLin A. majus (Schroeder, 2000) are reinforced with our data. Significant additive and dominance genetic variance components detected here in early generations agree with results obtained by Schroeder and Stimart (2001) using a generation means analysis population. Inconsistent magnitudes of heterotic deviation, from high parent PHL, suggest complex inheritance of the trait. Future work will attempt to resolve the complex inheritance patterns observed.

\section{Literature Cited}

Bicknell, R. 1995. Breeding cut flower cultivars of Leptospermum using interspecific hybridisation. N.Z. J. Crop Hort. Sci. 23:412-421.

Bobisud, C.A. and H. Kamemoto. 1982. Selection and inbreeding in Dendrobium (Orchidaceae). J. Amer. Soc. Hort. Sci. 107:1024-1027.

Burchi, G., C. Bianchini, A. Mercuri, G. Foglia, D. Rosellini, and T. Schiva. 1999. Analysis of post-harvest flower life in a cross between carnation cultivars with different ethylene responses. J. Genet. Breeding 53:301-306.

Burge, G.K.,E.R. Morgan, I. Konczak, and J.F. Seelye. 1998. Postharvest characteristics of Limonium 'Chorus Magenta' inflorescences. N.Z. J. Crop Hort. Sci. 26:135-142.

De, L.C., S.D. Wahi, and S.K. Bhattarcharjee. 1999. A post-harvest study of genetic divergence in cut roses. Indian J. Genet. 59:351-356.

Falconer, D.S. and T.F.C. Mackay. 1996. Introduction to quantitative genetics. 4th ed. Addison Wesley Longman Ltd., Edinburgh Gate, Harlow Essex, England.

Halevy, A.H. and S. Mayak. 1975. Interrelationships of several phytohormones in the regulation of rose petal senescence. Acta Hort. 41: 403-116.

Hallauer, A.R. and J.B. Miranda. 1988. Quantitative genetics in maize breeding. 2nd ed. Iowa State Univ. Press, Ames.

Harding, J.T., T. Byrne, and R.L. Nelson. 1981. Estimation of heritability and response to selection for cut-flower yield in Gerbera. Euphytica 30:313-322.

Heuser, C.W. and K.B. Evensen. 1986. Cut flower longevity of peony. J. Amer. Soc. Hort. Sci. 111:896-899.

Hvoslef-Eide, A.K., T. Fjeld, and J.W. Einset. 1995. Breeding Christmas begonia (Begonia $\times$ cheimantha Everett) for increased keeping quality by traditional and biotechnological methods. Acta Hort. 405:197-204.

Joyce, D.C. and P.R. Beal. 1999. Cutflower characteristics of terminal flowering tropical Grevillea: A brief review. Austral. J. Expt. Agr. 39: 781-794.

Krahl, K.H. and W.M. Randle. 1999. Genetics of floral longevity in Petunia. HortScience 34:339-340.

Littell, R.C., G.A. Milliken, W.W. Stroup, and R.D. Wolfinger. 1996. SAS system for mixed models. SAS Inst. Inc., Cary, N.C.

Mackay, W.A. and T.D. Davis. 1998. ‘Texas Sapphire' and ‘Texas Ice'longstem bluebonnets (Lupinus havardii). HortScience 33:348-349.

Marousky, F. J. and J.C. Raulston. 1970. Interaction of flower preservative components and light on fresh weight and longevity of snapdragon cut flowers. Proc. Fla. State. Hort. Soc. 27-29:445-448.

Muceniece, G.Y., I.D. Rasals, and V.Y. Dislers. 1978. Investigation of the inheritance of quantitative characteristics of Gerbera in diallel crosses.
I. Productivity of the plants. Soviet Genet. 14:160-162.

Nell, T.A. 1992. Taking silver safely out of the longevity picture. Grower Talks (June):35, 37, 39, 41-42.

Nyquist, W.E. 1991. Estimation of heritability and prediction of selection response in plant populations. Critical Rev. Plant Sci. 10:235-322.

Ohkawa, K. and E. Sasaki. 1999. Eustoma (Lisianthus) - Its past, present and future. Acta Hort. 482:423-426.

Ohkawa, K., K. Youichi, and J.S. Suh. 1999. Mobility and effects on vase life of silver-containing compounds in cut rose flowers. HortScience 34:112-113.

Onozaki, T., H. Ikeda, and T. Yamaguchi. 2001. Genetic improvement of vase life of carnation flowers by crossing and selection. Scientia Hort. 87:107-120.

Patil, S.S.D. and D.A. Rane. 1999. Studies on heritability estimates in China aster. J. Maharashtra Agr. Univ. 20:137-138.

Rogers, M.N. 1992. Snapdragons, p. 93-112. In: R.A. Larson (ed.). Introduction to floriculture. Academic Press, New York.

Satterthwaite, F.E. 1946. An approximate distribution of estimates of variance components. Biometrics Bul. 2:110-114.

Schroeder, K.R. 1995. Inheritance of postharvest longevity of cut stems in Antirrhinum majus L., snapdragon. MS thesis. Univ. Wis.-Madison, Madison, Wis.

Schroeder, K.R. 2000. A study on the genetics and physiology of cut flowers postharvest longevity in Antirrhinum majus L. PhD diss. Univ. Wis.-Madison, Madison, Wis.

Schroeder, K.R. and D.P. Stimart. 2001. Genetic analysis of cut-flowerlongevity in Antirrhinum majus. J. Amer. Soc. Hort. Sci. 126:200-204.

Steel, G.D. and J.H. Torrie. 1980. Principles and procedures of statistics. 2nd ed. McGraw-Hill Inc., New York.

Stieve, S.M. and D.P. Stimart. 1994. Genetic analysis of postharvest longevity in Antirrhinum majus L. HortScience 29:435 (abstr.).

van der Meulen-Muisers, J.J.M. and J.C. van Oeveren. 1996. Influence of variation in plant characteristics caused by bulb weight on inflorescence and individual flower longevity of asiatic hybrid lilies after harvest. J. Amer. Soc. Hort. Sci. 121:33-36.

van der Meulen-Muisers, J.J.M., J.C. van Oeveren, and J.M. van Tuyl. 1997. Breeding as a tool for improving postharvest quality characters in lily and tulip flowers. Acta Hort. 430:569-575.

van der Meulen-Muisers, J.J.M., J.C. van Oeveren, and J.M. van Tuyl. 1998. Genotypicvariation in postharvest flower longevity in Asiatic hybrid lilies. J. Amer. Soc. Hort. Sci. 123:283-287.

van der Meulen-Muisers, J.J.M., J.C. van Oeveren, J. Jansen, and J.M. van Tuyl. 1999. Genetic analysis of postharvest flower longevity in asiatic hybrid lilies. Euphytica 107:149-157.

van Eijk, J.P. and W. Eikelboom. 1980. Methods of selection in tulip breeding. Acta Hort. 109:217-225.

Wernett, H.C., G.J. Wilfret, T.J. Sheehan, P.M. Lyrene, F.G. Martin, T.L. White, G.L. Powell, and C.J. Wilcox. 1996a. Postharvest longevity of cut-flower Gerbera. II. Heritability of vase life. J. Amer. Soc. Hort. Sci. 121:222-224.

Wernett, H.C., T.J. Sheehan, G.J. Wilfret, F.J. Marousky, P.M. Lyrene, and D.A. Knauft. 1996b. Postharvest longevity of cut-flower Gerbera. I. Response to selection for vase life components. J. Amer. Soc. Hort. Sci. 121:216-221. 